\title{
EDUCATIONAL LIBRARIES IN EUROPE FOCUSSING ON GERMANY AND THE EUROPEAN SCHOOL NETWORK
}

by

\author{
Dr. Diann Rusch-Feja
}

\begin{abstract}
This article is a revision of a presentation given by the author at the Education Division Session during the 87' SLA Conference, June 9, 1997, in Seattle, Washington. It presents an in-depth analysis of European educational libraries with a distinct emphasis on Germany. The historical development, the building of databases, educational networks and information systems, the production of CD-ROMS, plus the broad range of library and research facilities and their services are examined in detail. Relevant lists of major European research institutions and the list of their abbreviations are provided in the appendices.
\end{abstract}

\section{Introduction}

\section{Educational Libraries in Germany}

Historical Development of Libraries Supporting Educational Institutions and Bibliography

In the early sixties, educational reforms were finally being enacted in Germany after the first reconstruction period following the Second World War. Consequently, the documentation units of eight educational research institutions ${ }^{1}$ began a cooperative effort in 1964 to coordinate the bibliographic information on educational resources in Germany. (See Appendix A). These eight documentation units chose the name "Dokumentationsring Pädagogik" (Documentation Ring for Pedagogics) which was best known under the acronym "DOPAED." Coordination of the efforts was first assumed by the Pädagogisches Zentrum (Pedagogical Center) in West Berlin, then by the German Youth Institute (Deutsches Jugendinstitut) in Munich in the 1970's. In the 1980's it was taken over by the Library of the Deutsches Institut für
Internationale Pädagogische Forschung - DIPF (German Institute for International Educational Research). In 1966, DOPAED produced the first volume of the Bibliographie Pädagogik ("Educational Bibliography") 2 with all newly registered titles of books and journal articles in the German language area including Austria and Switzerland in that year. The basis for indexing the books and articles of German language educational materials (excluding textbooks, lesson plans, curricula listings etc.) was the Thesaurus Pädagogik developed in the late sixties. ${ }^{3}$ This Thesaurus combines verbal descriptors with a classification scheme especially created for the Bibliographie Pädagogik and based on the German educational system. Publication of the Bibliographie Pädagogik continued on an annual basis.

In the early 1970's, within the overall plan for bibliographic information centers from the German Federal Ministry of Research and Technology, an Information Center for Education ("Fachinformationszentrum Bildung") was one of 20 such information centers planned for the Federal Republic of Germany. ${ }^{4}$

I The original eight documentational units of educational research institutions were the Pedagogical Center in West Berlin, the Max Planck Institute for Human Development and Education in West Berlin, the UNESCO Institute for Pedagogics in Hamburg, the Standing Conference of the State Ministries of Culture in Bonn, the German Institute for International Educational Research in Frankfurt, the Cybernetic Linguistics Research Center in Heidelberg, the International Central Institute for Youth and Educational Television in Munich, and the German Institute for Research on Youth in Munich.

2 Bibliographie Padagogik = Educational Bibliography. Ed.: Dokumentationsring Padagogik (DOPAED). Munich, New York, London, Paris, Saur, $1964 \mathrm{ff}$. (Reihe A, Reihe C (Projekte Bildungsforschung).

${ }^{3}$ Hans H. Strater: Thesaurus Padagogik. Unter Mitarbeit von Doris Freiedrich. Hrsg. v. Dokumentationsring Padagogik (DOPAED). Pullach bei Munchen: Verlag Dokumentation, 1973.

${ }^{4}$ Programm der Bundesregierung zur Förderung der Information und Dokumentation (IuD-Programm) 1874-1977. Bonn: Bundesministerium für Forschung und Technologie, 1976, for the planned educational information system (FIS Bildung) see p. 61; BMFT-Leistungsplan Fachinformation. Planperiode 1982-1984. Bonn: Bundesministerium für Forschung und Technologie, 1982 (in the accompanying table to this work, FIS 12 Bildung was noted as not yet realized and pending a Bund-Länder evaluation of the need; Fachinformationsprogramm 1985-88 der Bundesregierung. Bonn: Bundesministerium f ïr Forschung und Technologie, 1985. 
Of the 20 information centers, 16 were established, with the "Information Center for Education" being one of those which was not funded.

During the 1970's and 1980's -years which can be characterized in Germany as furthering subject-oriented databases and service - DOPAED attracted new members in the Federal Republic of Germany (West Germany at that time). By 1992, despite its voluntary nature, it was composed of the documentation units of 23 educational institutions. In this year, Bibliographie Pädagogik had a four-year publication delay. Title data for the production database had to be converted from at least eight different data formats and year, almost as many cataloging formats. This slowed production immensely. With the announcement of combined Federal and State (of Hesse) funding for a pilot project to establish a subject-information center for educational literature, the members of DOPAED made several decisions which would influence the next years. nature, it was composed of the documentation units of 23 educational institutions. The Federal/ State pilot project was to be based on the voluntarily assembled data collection of the unofficial DOPAED group which up to this time had had no financial support other than the work capacity of the institutions involved. The voluntary datacollection, then housed at the Library of the German Institute for International Educational Research (DIPF), was assumed by the government proposal as the basis for the new Coordinating Office for Educational Literature ("Fachinformationssystem Bildung" or "FIS-Bildung") without official recognition of the rights of the voluntary institutions. In 1991 an announcement was made regarding funding and organization of a FIS-Bildung (similar to the subject-oriented information centers "FIZ"), but little information filtered down to the contributing institutions. Aware of the negative aspects of the four-year publication delay of the annual Bibliographie Pädagogik, these institutions were also at a point, after over 20 years, to try to achieve better cooperation. Yet without financial means, the fundamental problems for data conversion and even publication using a different Republic of Germany (West Germany at that time). By 1992, despite its voluntary (electronic) form, could not be solved.

Further aspects deterred speeding up production of the Bibliographie Pädagogik. The institutional members, precisely because of the voluntary nature of the DOPAED group, could not put pressure on other members to achieve standards in bibliographic description, indexing or even application of the classification system on which the Bibliographie Pädagogik is based. Hence, the members themselves were dissatisfied with certain aspects, but were willing to take certain disadvantages into consideration due to the limited means by which standards would otherwise have to be enacted. When the announcement of the pilot project was made known to the DOPAED institutions, a meeting was called in November, 1991, with invited experts in the educational research field who were familiar with databases in educational literature. At first, because the DOPAED members felt threatened by the new organizational structure, a non-profit society was founded to represent the interests of these institutions and to advance better documentation of educational literature resources. This was the Society "Gesellschaft Information Bildung" (Society for Information in Education) which included not only most of the former DOPAED institutions, but also several educational

\begin{tabular}{|c|c|}
\hline Doc & $\begin{array}{l}\text { DOPAED } \\
\text { kumentationsring Padagogic } \\
\text { tion Ring for Educational Literature } \\
1964-1992 \\
\text { Bibliographie Pädagogik } \\
\text { (Thesaurus Pädagogik) }\end{array}$ \\
\hline $\begin{array}{l}\text { DOPAED Database } \\
\text { FIS-Bildung } \\
\text { Federal Pilot Project } \\
1997 \text { integrated into DIPF }\end{array}$ & $\begin{array}{l}\text { DOPAED Members } \\
\text { Gesellschaft Information Bildung, e.V. (GIB) } \\
\text { (Society for Information in Education, 1991) }\end{array}$ \\
\hline
\end{tabular}


researchers and publishers of electronic media in the educational field as well as librarians and documentalists in educational libraries and documentation centers. (See chart)

After a transitionary year (1992), DOPAED was dissolved. The members voted to commission the GIB with continued representation of their interests in the FIS-Bildung database and for the sales profits of the print volumes of the Bibliographie Pädagogik. Originally, the DOPAED group was to form a documentational section within the GIB. However, this would have excluded new members whose interests were also in documentation and indexing of educational materials, but who had not been previous members of the DOPAED Ring.

In 1992, after FIS-Bildung started, contracts were made with the individual institutions, thus establishing continuity in the production of the Bibliographie Pädagogik and continued delivery of their title entries for the database. Those agreeing to support the FIS-Bildung as they had previously supported DOPAED, with submission of title entries, were integrated as "Herausgeber" thus being recognized collectively as partial owners and publishers of the Bibliographie Pädagogik and the FIS-Bildung database for the production of the future CD-ROM.

\section{Gesellschaft Information Bildung}

Though the name of this organization was specifically chosen so as not to include limiting prepositions (for/on information, for/ on/about education), it is difficult to translate it into English without prepositions. Thus, the German Society for Information in Education (Gesellschaft Information Bildung - GIB) was founded by 8 former members of the DOPAED Ring, together with several active educational researchers, to improve the quality and dissemination of information on educational materials and research results, and to improve access to these. A special interest was in furthering access to electronic information, and especially in establishing quality electronic publications. The GIB supports the work of FIS-Bildung, as well as that of other educational research institutions and producers of databases and educational servers. The concept for the German Educational Resources Server originated in this group and active support has continued. The GIB holds annual conferences which often focus on the improvement of quality and access to bibliographic and full-text materials relevant to educational research and schools. http://www.educat.hu-berlin.de/gib/

\section{The Subject Information System for Education: Fachinformationsystem Bildung-FIS-Bildung}

Fachinformationssystem Bildung started as a pilot project for three years, 1992-1995. In 1995, funding was renewed for an additional year. The pilot project was financed in equal parts by the Federal Ministry of Research \& Technology (BMBF) and the State Ministry of Education of the State of Hesse. Thus, FIS -Bildung was conceived of as a coordinating unit for continuing the bibliographic indexing of educational materials started by DOPAED (Bibliographie Pädagogik). The fact that this was a subject-information system as opposed to a subject information center, (= "Fachinformationszentrum"), indicates its placement within the decentralized state-level authority for educational matters. Its foremost goal and function as a federal/state funded pilot project was to gather bibliographic data on educational materials to produce a comprehensive German language bibliography of educational materials and research results on a CD-ROM which could be cumulated annually. Representatives of the state authorities for educational policy did not want to have FIS-Bildung host an online database such as had developed out of the 1974 "Fachinformationsprogramm" in other subject areas such as the hard core sciences and technology.

The FIS-Bildung pilot project was not to perform indexing tasks directly. The staff allowance was for a director, a documentalist and 1.5 positions for database construction and data conversion. This meant that from the very beginning of FIS-Bildung, the data input was still dependent on the principle maintained by the former DOPAED Ring

Hence, contractual agreements were offered to the former DOPAED members to submit their bibliographic data for production of a CD-ROM with the remuneration of receiving the CD-ROM annually at no charge. Thus FIS-Bildung began with 12 contributors. 5 In 1994, a project group ("Projektgruppe Fachinformation Bildung " 6 ) sponsored by the German Research Foundation which was converting the former GDR database on

5Max Planck Institute for Human Development \& Education (MPIB), Standing Conference of the Cultural Ministers (KMK), University Library of Erlangen - Nuremberg (DFG Special Collections Library for Education and Teaching), the German Institute for International Educational Research (DIPF), Educational Center of the German Adult Education Society (PAS), Information Center for Foreign Language Research (IFS), Bavarian State Institute for Research and Planning in Higher Education (1993) (IHF), German Youth Institute (DJI), Catholic Religious Education Documentation Unit (1993) (KRD), State Institute for School Pedagogy and Educational Research (ISP), Comenius Institute (CI) - Comenius Institute, State Institute (of Northrhein-Westfalen) for Schools and Continuing Education (LSW), Hessian Institute for Educational Planning and School Development (HIBS), Departmental Library of the Austrian Federal Ministry for Teaching and Art (BMfUK).

6 This Projektgruppe Fachinformation Bildung was closely connected to the Projektgruppe Hochschulforschung (PHSF) - Interim Project Group for Research of Higher Education which constituted those research areas and researchers of the former GDR Zentralinstitut fur Hochschulforschung (Central Institute for Higher Education Research) continued after the dissolution of this latter institute in December, 1989. 
higher education materials, joined the group of contributors. This database was integrated into the FIS-Bildung database in 1996. In 1995, the former GDR database for primary and secondary school educational materials was converted by the FIS-Bildung staff and integrated into the data collection. In the process of this cooperation with contributors of education databases of the former GDR, the most relevant parts of historical bibliographical data could be implemented into the FIS-Bildung database. By the end of 1997, 21 institutions from both the old and the new German states (former GDR) had joined the contributors' group to FIS-Bildung.

In addition, FIS-Bildung was to continue production of the Bibliographie Pädagogik on an efficient, timely basis. Orginally seen as a by-product of compiling the CD-ROM database, production of the printed Bibliographie Pädagogik (as of the volume covering the publication year $1986 \mathrm{ff}$.), was to take place parallel to the CD-ROM production. Thus the original database, supplied by the voluntary contributing institutions, would then serve as a basis for starting FIS-Bildung and the production of an electronic, searchable version of the complete database of all German-language educational materials on CD-ROM from 1964 to the present which had previously been indexed only on an annual basis in the Bibliographie Pädagogik.

Production of the CD-ROM and Bibliographic Database for Education Research and Materials "CD-BILDUNG" - "CD-Education"

A policy decision for the production of the CD-ROM "CD-BILDUNG" was made from the very beginning. As opposed to the Bibliographie Pädagogik, the CD-BILDUNG (CD-ROM database) would include not only German-language, or documents produced in German institutions, but all information sources on education and schools held in the contributing institutions as well as all foreign materials dealing with the German education system. This meant that titles of articles from approximately 60 foreign journals would also be included in the database as they were held in at least one of the contributing German institutions. In certain situations, German-language texts published abroad, as well as English-language articles, books, or book chapters published abroad, would also be included if the author was employed at a German institution at the time of authoring the article, book, or book chapter. This not only brought a wider scope into the database, but also a greater searchability.

The initial task in preparing this database needed for the CD-ROM was the selection of database management systems and conversion of the DOPAED database which then held the complete German language bibliographic data up to publication year 1986. Parallel to this, conversion formats of the 12 contributors' data were being developed in various formats. An adequate database structure was found to accommodate not only the bibliograhic entries themselves, but also notes regarding the source library or documentation unit submitting the selected title entry and others which also had this work in their collection. Later, an extensive thesaurus maintenance module was integrated so as to distinguish local subject headings from those taken from the Thesaurus Pädagogik developed by DOPAED. In the case of multiple contributors submitting the same title entry, the following selection criteria were used as priorities: 1) the inclusion of an abstract; 2) the most accurate title entry would take preference; or 3) the title entry with the most detailed content indexing would be preferred. Because the German library cataloging rules only allow for the first three authors, title entries for works by multiple authors were preferred when they included all the authors' names.

The first edition of the CD-BILDUNG came onto the market in 1994 and covered bibliographic data for works from the publication years 1980-1993. The fourth edition in 1997 had 341,928 title entries of which $10 \%$ were English (15\% were nonGerman including English) and $26.3 \%$ had abstracts. Holdings information give an abbreviation of the holding institution(s), and in the case of journals, the exact volume and year of holdings, with a note about the use restrictions of the individual institutions. At the end of 1997, 21 institutions had contributed bibliographic data to FIS-Bildung for the production of CD-BILDUNG and there are annual additions of title entries ranging from 30,000 to 60,000 .

Schools received reduced rates. The annual subscription for CD-BILDUNG is DM 399, but it costs DM only 100.00 for school use. As of 1998, CD-BILDUNG will include the Directory of the German Society of Educational Researchers ("Deutsche Gesellschaft für Erziehungswissenschaft"- DGfE) and be available to those members at a discount rate. Refinement of the German Educational Thesaurus and Classification System (Thesaurus Pädagogik) is an ongoing, dynamic process which has involved several workshops sponsored by FIS-Bildung and the GIB.

The pilot project phase ended on December 31, 1996 and since January 1, 1997, FIS-Bildung has been fully integrated into the German Institute for International Educational Research (DIPF) as one of the Service Units. Since early 1998, FIS-Bildung offers updates to the current edition of the CD-BILDUNG on a continuous basis at the DIPF Website: http://www.dipf.de/lars/ lars.html.

\section{Major Educational Research \& Documentational Units in Germany in 1997}

\section{A. The German Institute for International Educational Research (DIPF)}

In Germany culture and education are state supported and administered. Exceptions are the "Blue List" of approximately 70 research institutions deemed "culturally valuable," hence worthy of both state and federal financial support, and with more than 
regional responsibilities. They are financed jointly by the federal government and the state Ministry of Education and Culture in the state in which the individual institution is located. Founded in 1951, the German Institute for International Educational Research is one of these "Blue List" institutions. In 1997, DIPF had 55 researchers and a total of 120 staff members. The major areas of educational research include:

General and comparative educational research

Economics of education

Educational psychology

Educational law and administration

Sociology of education

History of education (in Berlin).

As of 1991, the Federal-State-Commission (Bund-Länder -Kommission) recommended that the institutions belonging to the former GDR Academy of the Pedagogical Sciences (Library, Archives, Central Documentation Unit for Educational Literature and Research Unit) be assured continued funding on the basis of integration into DIPF. Since that time, DIPF has maintained the Library for the History of Education Research (BBF) in Berlin and the research group of educational historians working there.

The Service Units of DIPF include:

The Frankfurt Research Library (DFF) former "German Teachers' Library” (Deutsche Lehrerbibliothek)

The Library for Historical Educational Research (BBF) (Berlin) (Bibliothek für Bildungsgeschichtliche Forschung)

The Information and Documentation Unit (Frankfurt) (Dokumentation)

FIS-Bildung (as of 1997).

\section{The Service Unit of DIPF: Its Libraries and IuD (Information and Documentation)}

\section{The Frankfurt Research Library (DFF) - Frankf urter Forschungsbibliothek}

The Frankfurt Research Library in DIPF includes the Frankfurt Teachers' Library which is a public library supported by the city of Frankfurt. This part of the collection by nature of its history can circulate, but the library does not participate in the German interlibrary system, so the collection can only be used by persons who come to the library. In addition, the Frankfurt DIPF library serves as the research library for the researchers in the DIPF institute. From the early eighties to 1992, it was the coordinating unit for the DOPAED Ring for production of the Bibliographie Pädagogik. In addition, the library produces a database for educational media (Medienpädagogik) and maintains a comprehensive newspaper clipping archive for educational topics ("Zeitungsdokumentation Bildungswesen").

\section{The Library for Historical Education Research (BBF) Bibliothek für Bildungsgeschichtliche Forschung (Berlin)}

This library has a long history of being a key educational materials library for Germany. In the 19th century it was the German School Museum of the Berlin Teachers' Society. In 1908 it became the German Teachers' Library (Deutsche Lehrerbibliothek). From 1933-1945, it was renamed the Library of the National Socialists' Teachers' Organization. After the Second World War and the division of Berlin, because this geographical part of Berlin belonged to the East (Soviet-regulated) Sector of Berlin, it became, from 1951 on, the Pedagogical Central Library of the former German Democratic Republic (GDR). Extensive exchange agreements with other communist countries provided the basis for a very comprehensive collection of primarily East European educational materials and research results. From 1970-1990, the library was integrated into the GDR Academy of the Pedagogical Sciences (Akademie der pädagogischen Wissenschaften - APW). In 1990, the academy was dissolved and the librarian, Dr. Marion Bierwagen, found supporters for the library through a "Friends of the Library" initiative and through appeals to the Berlin Senate and other sources of funding for preservation of cultural heritage institutions. In 1992, the library was integrated into the German Institute for International Educational Research Institute (DIPF) through a decision of the Federal-State Commission. After dissolution of the APW, some of the scientific staff from the former documentation unit of the former GDR Academy of Pedagogical Sciences were employed in the information and documentation unit in DIPF, Frankfurt, and some of the researchers of the former APW-primarily educational historians-found a new home in the Berlin annex of DIPF in rooms connected to the library with the library collection as the focal point of their research. In addition to the library and researchers, the archives of the GDR Academy of Pedagogical Sciences were given a home in the library which obtained a new building in 1994. This building-indicative of post-Berlin Wall renovation efforts-was a former factory and is today one of the most beautiful and inviting, yet extremely practical libraries of Germany.

With integration into the German Institute for International Educational Research Institute, the former Pedagogical Central Library became renamed the Library for Historical Educational Research (Bibliothek für Bildungsgeschichtliche Forschung - BBF). At the end of 1997, it housed ca. 679,000 volumes of which approximately 38,000 are works produced between 1496 -1900 . Since the library collections experienced only minor damage during the war, the collection offers an educational historian a vast amount of unique literature and textbooks not 
otherwise held in German educational libraries. ${ }^{7}$ The library subscribes to 494 current periodicals in the area of educational research and publishes bibliographies and other relevant publications relating to the collection. Digitization and retrospective conversion projects are currently underway. The library organizes larger historical exhibitions and cultural events. Library staff work closely with the educational historians in preparing further bibliographies and research works.

\section{The Information and Documentation (IuD) Unit of DIPF}

This unit is responsible for bibliographic support and information retrieval for the researchers in DIPF. The unit, composed of 4 scientific staff, also evaluates certain journals cover-to-cover, producing title entries and abstracts for the articles which are then integrated into the FIS-Bildung database. In addition, profile topics and other databases have been created, including European education and others.

\section{DIPF's Future as a Service Institution}

The above situation depicts the German Institute for International Educational Research Institute up to the end of 1997. After evaluation in 1997 by the German Scientific Council ("Wissenschaftsrat"), DIPF has lost its "Blue List" standing for parts of its structure. The service units, especially the integration of FIS-Bildung, were positively evaluated and will continue to receive funding. The staff of FIS-Bildung has now received permanent funding within DIPF, although other areas of the service units will be slightly reduced. Support for the BBF will also maintain its level of service and collection development; certain transitionary staff may expand into permanent positions. However, the evaluation of the entire institute has enhanced the status of the service units, giving them a new, more national role to play in terms of establishing more services which function to describe the German educational system outside of its borders and to provide German-language information on the educational systems of other countries for German policy makers, comparative educationalists and researchers. This focus will be developed during the coming three to four years. http://www.dipf.de/

\section{B. The Max Planck Institute for Human Development and Education}

Founded in 1962, the Max Planck Institute for Human Development and Education ${ }^{8}$ is one of approximately 75 Max Planck Institutes devoted to basic research. This institute was founded by Helmut Becker at a time of educational reform in the post-World War II era. Its researchers were involved in giving formal recommendations for reform of the higher education system in and in various aspects of the school system and curriculum reform in (then)West Germany and West Berlin. After restructuring into a multi-director Max Planck Institute, the institute had four research centers. From 1982-1996, the education research center was devoted to School Systems and Instruction, and the head of this research center was Prof. Dr. Peter Martin Roeder. After Prof. Roeder's retirement, Prof. Dr. Juirgen Baumert took over the directorship of this research center in May 1997. The focus of research shifted to the Center for Educational Research, focussing on educational systems and educational research. The major differences lie in the changed approach to research in this field. These are:

- Systems Theory Approach: the educational system is a functionally specific subsystem of society.

- Institutions Orientation: the institution determines structure of opportunities for, and constraints on, individual learning and development.

- Structural Paradox of Institutionalized Education: learning within educational institutions is confined to the structure of the institutions and is of ten very different from learning outside school -like institutions.

- Dual Time Frame of Institutionalized Education: educational processes are directed to future life situations which require responsible, autonomous action.

The research projects of this research center are:

1. Learning, Process, Educational Careers and psychosocial development in adolescence (BIJU)

1.1. Expansion of the Educational System and Cognitive Mobilization

1.2. Development of Competence and Personality: Transformation of the Educational System in East Germany

1.3. Political Socialization and the Transformation of the East German System

${ }^{7}$ A very good textbook collection, however, is available at the Library of the Georg Eckhardt Institute for School Book Research in Brunswick (Georg-Eckhardt-Institut firr Schulbuchforshung in Braunschweig).

8 After 1997, this Max Planck Institute has changed its name to Max Planck Institute for Human Development (subsuming the aspects of Education into the broader Human Development). 
1.4. Mastering the Transition from School to First Vocational Training under the Conditions of a Restricted Training Market

1.5. Mathematics and Science Education in International Perspective (including the Third International Mathematics and Science Study (TIMSS-Germany)

1.6. Civic Education Revisited: Political Education from an Intercutlural Point of View

1.7. Structural Change of the GDR School System: Data Handbook on Educational History

2. Motivational and Affective Regulation of Learning Behavior

2.1 Task-Irrelevant Cognitions and Individual Learning Processes

2.2. Goal Orientation and Development of School Performance

2.3. The Development of Interests and Performance in Adolescence.

3. Tasks of Optimization in Teaching / Learning Processes

3.1. Multicriterial Goal Structure of Instruction: Compatibility of Cognitive and Noncognitive Goals

3.2. Conflicting Goals and Multicriterial Effectiveness of Instruction: Compatibility of Optimal Encouragement of Performance \& Reduction of Divergence

3.3. Mathematics Teaching in Germany, Japan, and the United States.

4. Improving Cognitive Competencies in Elementary School: The ENTERPRISE Project

5. Fields of Special Methodological Applications

5.1. The Multilevel Analyse Paradigm for Statistical Modeling of Hierarchically Structured Data Sets and Measures of Change

5.2. Typological Analyses by Means of the Mixed Rasch Model

6. The Berlin Forum on School Legislation

For further details, the reader is referred to the project descriptions in the Center's Brochure or in the Institute's 1996 Annual Report.
The Library and Research Documentation Unit of the Max Planck Institute for Human Development and Education

The Library and Research Documentation Unit of this institute has over 174,000 volumes with an annual growth of approximately 3200 items. The library subscribes to 715 current periodicals and possesses approximately 32,000 bound periodicals. The library is not open to the general public. The library and its holdings are available to users on site which includes 180 institute members and approximately 80 guests per year. The collection includes the following major areas of emphasis: educational research, educational theory, educational systems, schools, school laws, teachers and teacher training, professionalism, teaching and curriculum development, school achievement, transition from school to work, socialization, sociology and society, work, transformation processes, workforce, economics, life span development, psychology, developmental psychological, evolutionary psychology, psychological research, cognition, cognitive development, gerontology, aging and cognition, aging, etc.

Segments from the library catalog (http://www.mpib -berlin.mpg.de/dok/ehome.htm) are submitted to FIS-Bildung. The library catalog has been converted to an electronic catalog including the complete holdings from 1970 onward and selectively from the acquisitions years of 1962-1969. The 14-person staff includes 2 full-time research staff who also study citation analyses, developments in scholarly publications and the transition to electronic media in (http://www.mpib-berlin.mpg.de/dok/ech.htm) which has been expanded in some cases to include not only electronic sources but a mixture of both print and electronic sources according to the needs of the projects. ${ }^{9}$

\section{Other Educational Research Institutions in Germany}

Figure 1, which appears at the end of the article, is a map indicating the current locations of some 20 major educational research institutions in Germany, Austria, and Switzerland. In addition to those already covered in some detail, these include: the Federal Institute for Vocational Training (BIBB), the Berlin Institute for Teacher Education and Further Education (BILS), the Information Center IDES (Berne, Switzerland), the Pestalozzi Research Center (Zurich, Switzerland), the Institute for Teaching Mathematics of the University of Bielefeld (IDM), the Secretariat of the Standing Conference of the Cultural Ministeries (KMK), the University Library of Erlangen-Nuremberg (UB-SSG) with the DFG Special Collections Library forEducation and Teaching, the German Institute for Adult Education (DIE), the Subject

${ }^{9}$ For more on the MPIB Clearinghouse, see Diann Rusch-Feja. (1997). Subject-Oriented Collection of Information Resources from the Internet: A Clearinghouse Concept to Support Scientists in a German Research Institute. Libri, v47 nl p l-24. 
Information Center in Karlsruhe (FIZ), the Institute for Teaching the Natural Sciences of the University of Kiel (IPN), the Library for the Hearing and Speech-Impaired (part of BBF, DIPF) (HSB) in Leipzig, the German Youth Institute (DJI), the Institute for Film and Pictures in Science and Teaching (FWU), the Bavarian State for School Pedagogy and Educational Research (ISP), the Institute for Labor Market Research of the Federal Labor Office (IAB), the Institute for Higher Education Research Wittenberg e.V. (IHS), and in Austria, the Departmental Library of the Austrian Federal Ministry for Teaching and Art (BMfUK). Further information on these institutions can be obtained from the author.

\section{Building the Internet Educational Network in Germany}

\section{The German Educational Resources Server (GER / DBS) — Deutscher Bildungsserver}

In 1995, at an annual meeting of the German Society for Information in Education (Gesellschaft Information Bildung - GIB), a suggestion was made for a nationwide educational resources server. 10 This suggestion for an encompassing World Wide Web Server listing publications, teaching and learning materials, and connecting them with directories of teachers, schools, educational researchers, university departments, etc., involved in education, was then worked into a proposal by Professor Peter Diepold of the Department of Pedagogics and Informatics of the Humboldt University of Berlin to the German Research NetworkAssociation (DFN - Deutschen Forschungsnetz Verein). The Server concept was granted funding for three years (1996 -1999) and Prof. Diepold chose the name: Deutscher Bildungsserver (DBS) (on its English pages, German Educational Resources - GER). This Server (http://dbs.schule.de) includes publications, links to major educational libraries, databases, major textbook publishers, the directory of the German Society of Educational Researchers (Deutsche Gesellschaft für Erziehungswissenschaft DGfE), the German School Web (http:// www.schule.de), and many other information sources relevant to educationalists, teachers, school administrators and students.

Perhaps the greatest achievement in this server thus far is the database for teaching and learning materials (Unterrichtsmaterialien und Projekte) which currently includes approximately 3400 entries for electronic documents, software, multimedia/interactive learning programs, CD-ROMs, books, etc. Using Dublin Core Metadata and several additional categories of metadata necessary for the German Educational Resources database, these items can be searched, and the metadata entries will also be used as filtering mechanisms. The actual items are in distributed systems all over Germany and also outside of Germany, the metadata can be entered using a template designed for this purpose and stored in a database to be searched using a Harvest search engine. The same template is used at 8 of the 16 State Educational Authorities' Servers, so there is complete standardization concerning the use of metadata and the retrieval mode. It is expected to connect this database with other databases at a later time so as to have active links between authors, schools, university departments of education and teacher training institutes, courses and curricula, publications and members of the university departments, societies, etc. It is expected that when the DFN funding period comes to a close, the responsibility for maintaining the German Educational Resources Server will be shared as of the year 2000 by the service units of the German Institute for International Educational Research (DIPF) (re: educational research) and the Institute for Film and Pictures in Science and Teaching (FWU) (re: school and teaching materials aspects).

At the same time as the German Educational Resources Server was being developed, several other school-oriented server architectures were evolving in Germany. Teachers took the initative and started the Open School Network (ODS). A Federal Project for Schools on the Network (SAN e.V.) was financed by the federal minister who provided money for schools to obtain hardware, thus reducing networking costs in being connected to the Internet. This was also supported by the WIN-SHUTTLE program of the German Research Network which supported a special connection for schools with a reduced rate. Since the cultural ministry in each individual German state has jurisdiction over the educational system in that state, some states more than others encouraged the development of computer classes and school networking courses. Baden-Wuerttemburg and Bavaria have developed individual information infrastructure programs which include programs for computer classes in primary and secondary schools. Other states have no special programs and in some cases individual innnovative teachers or schools are initiating course work in using computers and the Internet as an information source.

\section{The State Educational Authorities' Servers (Landesserver)}

Each German state has its own educational authority and many of these also have an educational information server which it supports or which members of that authority have taken the initiative to build up to support educational institutions in that German State. The sources of these state educational servers serve different needs. Those sponsored by the state governments also

${ }^{10}$ Diann Rusch-Feja: German Educational Resources: Eine Sammelstelle für deutsche erziehungswissenschaftliche und bildungsbezogene Quellen im Internet. In: Information im Bildungswesen-Zugriff, Verfügbarkeit und Qualität. 3. GIB-Fachagung, 22-23. November 1995 in Soest. Hrsg. D. Rush-Feja, P. Diepold, B. Christopher. Berlin: Gesellschaft Information Dildung, 1996, pp.147-55. 
include additional information on school policy, etc. Those sponsored by continuing education institutes for teachers or teacher training institutes for computer instruction offer different services and information. However, all these servers cooperate with the German Educational Resources Server and meet in Berlin twice a year to discuss technical issues, organizational problems, problems of establishing quality, use of metadata and meeting the requirements of their audience (teachers, students, administrators, school authorities). In addition to the German Educational Resources Server (DBS) and the network of state servers being built up in conjunction with the DBS, there is also an independent server registering educational materials in the Internet (Zentrale für Unterrichtsmedien im Internet e.V.) (http://ilsebill.biologie. uni-freiburg.de/schule/) sponsored by instructors and teachers in Freiburg.

Anyone wishing to access these individual servers can obtain the applicable website from the author. E-mail: ruschfeja@mpib-berlin.mpg.de

\section{The European SchoolNet (EUN)}

In 1996, a European Union proposal focussed on establishing an electronic school network for all of Europe. The proposal was accepted and the Swedish Educational Ministry has served as the coordinating unit for building an educational network within Europe.

The original goal was to have a prototype of an Europa-wide school server which would serve as a basis for various phases of development thereafter. Planning for this began in December 1996, with the proposal "Towards an Electronic Network for Schools" by Ylva Johansson, the Swedish Minister for Schools and Adult Education. In this proposal, Ms. Johansson gave the goals of this project, which were totally in accordance with the goals of the European Council set forth in June of 1996 in Firenze. The result of this was a resolution in the European Council recommending development of an educational, multimedial software and networked information for all of Europe. This resolution included the following goals for a Europa-wide School Network: -to ensure that pupils have net access to computers, software, networks, etc.

-to organize teaching and learning to include information technology in all subject areas

-to enable pupils to acquire necessary information technology knowledge and skills

-to further development of educational multimedia

-to promote European cooperation

Additional goals of the European SchoolNet include stimulating the development of multimedial teaching and learning software, further development of teacher training and continuing education courses in using new technology in the classroom, and instruction in expanding the consciousness of the vast educational potential of audiovisual and multimedial teaching and learning instruments in the network.

During the early months of 1997, various meetings of technical and content experts resulted in two principle papers: "The EUN Technical Platform-Strategy and Guidelines" and a "List of Suggested Areas on the Main EUN-Platform." In these papers, the thematic content and technical basis for the project is explained. The EUN should serve to bring together all existing networked educational systems as well as other educational institutions, make their offerings accessible and searchable using metadata.

Multilinguality of the project has been given a high priority. A supervisory council (EUN editorial board) as well as a technical commission (EUN Technical Network ETN) will provide support for the services of a central server (which will initially serve as the "Hub" of the entire distributed system) and also for the development and integration of individual servers in the member countries. Furthermore, development of educational servers, especially in those areas which do not as yet have such servers, will be supported by these commissions. Additional links and information on school projects and links to existing national school networks in the European countries can be found at the European SchoolNet Server (http://www.eun.org). Coordination of the German participants lies with Michael Drabe (German Minister forEducation and Research, the program: Initiative Schulen ans Netz, e.V. (http://www. san-ev.de)). The German Educational Resources Server under the direction of Peter Diepold will also participate in the development of metadata standards and other aspects of the EUN project. 


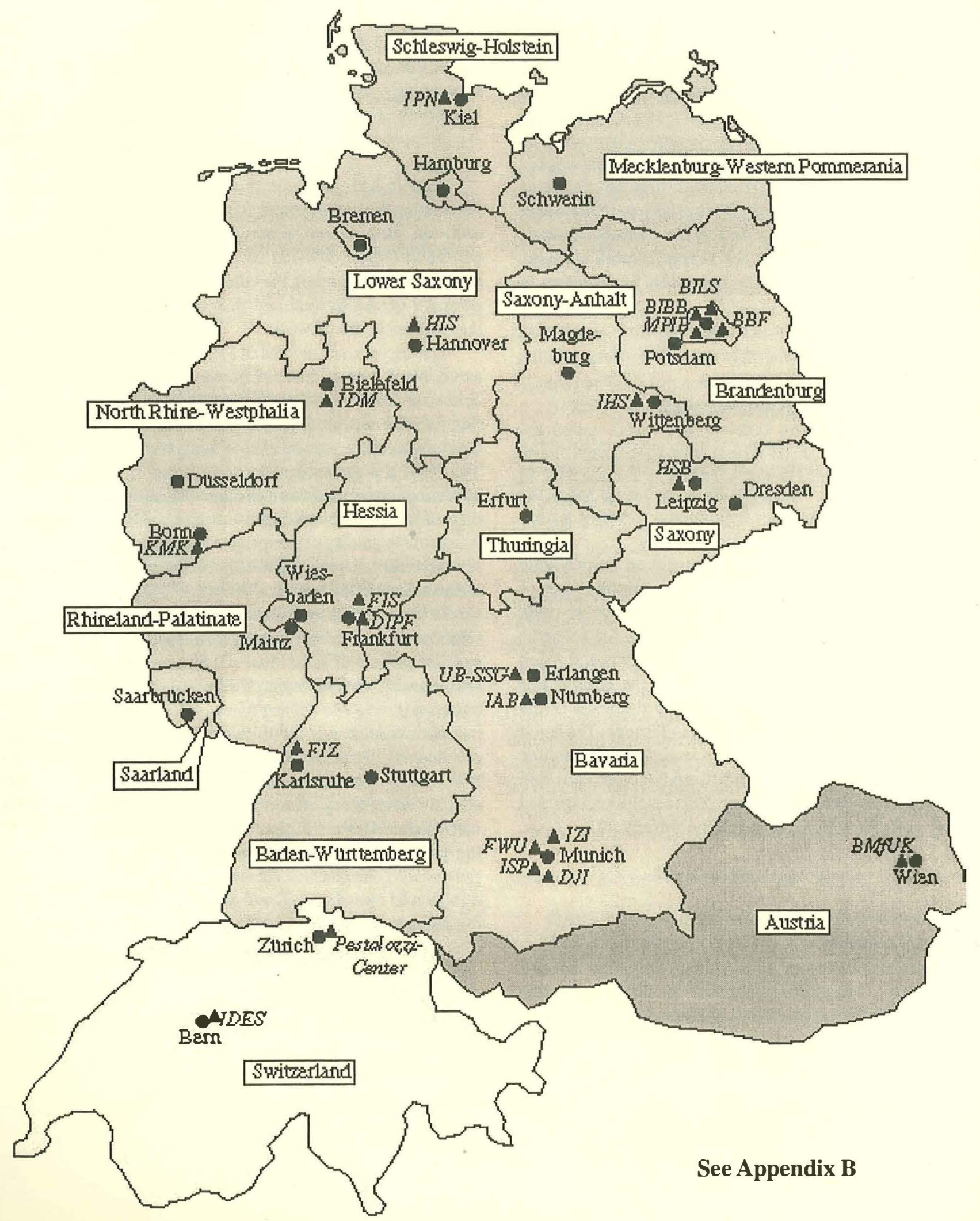




\section{APPENDIX A}

\section{Alphabetical List of Institutions According to English Names}

(Note: The 8 original educational and research institutions founded in 1964 are starred in the following list.)

Austrian Institute for the Study of Youth (Österreichisches Institut für Jugendkunde, OIJ) in Vienna

Austrian Library of the Federal Ministry for Teaching and Art (Amtsbibliothek des Bundesministeriums für Unterricht und Kunst, BMfUK) in Vienna

Bavarian State Institute for Research and Planning in Higher Education (Bayerisches Staatsinstitut für Hochschulforschung und Hochschulplanung, IHF) in Munich

Bavarian State Institute for School Pedagogy and Educational Research (Staatsinstitut für Schulpädagogik und Bildungsforschung, ISP) in Munich

Berlin Institute for Continuing Education of Teachers and School Development (BIL) (formerly Educational Center of Berlin, Pädagogisches Zentrum - PZ) (Berliner Institut für Lehrerfort-und-weiterbildung und Schulentwicklung)

Catholic Religious Education Documentation Unit (Katholisches Religionspädagogische Dokumentationsstelle, KRD) in Munich

Comenius Institute (CI) (Comenius-Institut Evangelische Arbeitsstätte für Erziehungswissenschaft) in Münster

*Cybernetic Linguistics Research Center (Sprachkybernetisches Forschungszentrum Heidelberg, SFZ) in Heidelberg

Department for Comparative Educational Research of the Ruhr University in Bochum-Arbeitsstelle für vergleichende Bildungsforschung an der Ruhr-Universität Bochum (AVB)

Educational Center Berlin( (Pädagogisches Zentrum Berlin (PZ) — (later Berlin Institute for Continuing Education for Teachers and School Development - BILS, as of 1995))

Educational Center of the German Adult Education Society (PAS) (Pädagogische Arbeitsstelle des Deutschen Volkshochschulverbandes e.V., PAS) in Frankfurt as of 1997 German Institute for Adult Education (DIE) (Deutsches Institut für Erwachsenenbildung)

Federal Educational Library in the State School Board of Lower Austria (BPD) (Bundesstaatliche Pädagogische Bibliothek beim Landesschulrat für Niederösterreich)

Federal Institute for Vocational Training (Bundesinstitut für Berufsbildung, BIBB) (West-Berlin)

German Educational Resources (DBS) (Deutscher Bildungsserver)

German Institute for Adult Education (DIE) (Deutsches Institut für Erwachsenenbildung) (Frankfurt) (formerly Pädagogische Arbeitsstelle des Deutschen Volkshochschulverbandes (PAS))

German Institute for Distance Education (Deutsches Institut für Fernstudien an der Universität Tüibingen, DIFF) in Tübingen *German Institute for International Educational Research (DIPF) (Deutsches Institut für international Pädagogische Forschung in Frankfurt

*German Institute for Research on Youth (DJI) (Deutsches Jugendinstitut) in Munich

German Society for Information in Education (GIB) - Gesellschaft Information Bildung (GIB) e.V. (headquarters in Berlin) Hessian Institute for Educational Planning and School Development (Hessisches Institut für Bildungsplanung und Schulentwicklung, HIBS) in Wiesbaden

Information Center for Foreign Language Research (Informationszentrum für Fremdsprachenforschung der PhilippsUniversität, IFS) in Marburg

Information Center IDES (Bern, Switzerland)

Institute for Didactics of Mathematics of the University of Bielefeld (IDM) (Institut für Didatik der Mathematik an der Universität Bielefeld) 
Institute for Film and Pictures in Science and Teaching (Institut für Film und Bild in Wissenschaft und Unterricht, FWU) in Munich

Institute for Higher Education Research Wittenberg (IHS) (Institut für Hochschulforschung Wittenberg e.V.)

Institute for Labor Market Research of the Federal Labor Office (IAB) (Institut für Arbeitsmarkt-und-Berufsforschung der Bundesanstalt für Arbeit)

Institute for Teacher Training of the Vienna University (Institut für Pädagogik an der Universität Wien, IP) in Vienna

*International Central Institute for Youth and Educational Television (Internationales Zentralinstitut für das Jugend-undBildungsfernsehen, IZI) in Munich

Library for Historical Educational Research (Bibliothek der Bildungsgeschichtlichen Forschung, BBF) (Berlin)

*Max Planck Institute for Human Devolopment and Education (Max-Planck-Institut für Bildungsforschung, MPIB) in West Berlin

*Pedagogical Center (Pädagogisches Zentrum, PZ) in West Berlin (after 1995, Berliner Institut für Lehrerfort-undweiterbildung und Schulentwicklung, BILS)

Pestalozzi Center — Pestalozzeum (Zurich, Switzerland)

Project Group Subject Information on Higher Education (IHS) - Projektgruppe Fachinformation Bildung (closely connected to the Projektgruppe Hochschulforschung) (PHSF) - Interim Project Group for Research of Higher Education (part of former GDR Zentralinstitut für Hochschulforschung) (ca. 1993-5 Bibliographic Database GDR Higher Education)

School Web (SW) - Schulweb (Directory of Schools on the World Wide Web maintained by the Dept. of Pedagogics and Informatics of the Humboldt University Berlin

*Standing Conference of the State Ministries of Cultıre (Ständige Konferenz der Kultusminister der Länder, KMK) in Bonn

State Institute of Northrhein-Westfalen for Schools and Continuing Education (Landesinstitut für Schule und Weiterbildung, LSW) in Soest

Subject Information Center Karlsruhe (Fachinformationszentrum Karlsruhe — FIZ)

Teacher Training Departments of 4 universities (Kassel, Koblenz, Halle, Munich in a cooperative agreement of Teacher Training Institutes for Physics to contribute to FIS-Bildung since 1997) (Physikdidaktischer FB der Universitäten Kassel, Halle, Koblenz, Miinchen)

*UNESCO Institute for Pedagogics (UNESCO Institut für Pädagogik, UNIP) in Hamburg

University Library of Erlange-Nuremberg (UB-SSG) DFG Special Collections Library for Education and Teaching Universitätsbilbiothek Erlangen-Nürnberg - DFG Sondersammelgebietsbibliothek Bildung/Erziehungswissenschaft

\section{List of Abbreviations}

\section{APPENDIX B}

AVB - Department for Comparative Educational Research University of Bochum (Arbeitsstelle für vergleichende Bildungsforschung an der Ruhr - Universität Bochum)

BBF - Library for Historical Educational Research (Bibliothek der Bildungsgeschichtlichen Forschung (formerly the library of the GDR Academy of the Pedagogical Sciences, since 1992, this library and a connected research staff of ca. 10 persons became part of DIPF)

BIBB - Federal Institute for Vocational Training - Documentation (Bundesinstitut für Berufsbildung) (Berlin)

BILS (BIL) - Berlin Institute for Teacher Education and Further Education (Berliner Institut fürLehrerfort-und-weiterbildung und Schulentwicklung, formerly Pädagogisches Zentrum Berlin (PZ) - Educational Center Berlin)

BMFUK - Departmental Library of the Federal Ministry (of Austria) for Teaching and Art (Amtsbibliothek des Bundesministeriums für Unterricht und Kunst) (Vienna) 
BPD - Federal Educational Library in the State School Board of Lower Austria (Bundesstaatliche Pädagogische Bibliothek beim Landesschulrat für Niederösterreich)

CI - Comenius Institute - Protestant Workshop for Education (Comenius-Institut - Evangelische Arbeitsstätte für Erziehungswissenschaft) (Münster)

DBS - Deutscher Bildungs-Server (German Educational Resources Server) (Berlin)

DIE - Deutsches Institut für Erwachsenenbildung - German Institute for Adult Education (Frankfurt) (formerly Pädagogische Arbeitsstelle des Deutschen Volkshochschulverbandes (PAS))

DIFF - German Institute for Distance Education (Deutsches Institut für Fernstudien an der Universität Tübingen) (Tübingen)

DIPF - German Institute for International Educational Research (Deutsches Institut für Internationale Pädagogische Forschung) (Frankfurt)

DJI - German Institute for Research on Youth (Deutsches Jugendinstitut) (Munich)

FIS - Coordinating Office for Educational Literature (FIS-Bildung — Fachinf ormationssystem Bildung) (Frankfurt)

FIZ - Subject Information Center Karlsruhe (Fachinformationszentrum Karlsruhe, since 1996)

FWU - Institute for Film and Pictures in Science and Teaching (Institut für Film und Bild in Wissenschaft und Unterricht) (Munich)

GER - German Educational Resources Server (Berlin) (Deutscher Bildungsserver)

GIB - Society for Information in Education (Gesellschaft Information Bildung, nationwide, headquarters in Berlin)

HIBS - Hessian Institute for Educational Planning and School Development (Hessisches Institut für Bildungsplanung und Schulentwicklung) (Wiesbaden)

HIS - Higher Education Information System (Hannover) (Hochschulinformationsystem)

HSB - Library for the Hearing and Speech-Impaired (Hör-und Sprechbedinderte Bibliothek) (part of BBF, DIPF)

IAB - Institute for Labor Market Research of the Federal Labor Office (Institut für Arbeitsmarkt-und Berufsforschung der Bundesanstalt für Arbeit)

IDES - Information Center IDES (Informationsstelle IDES) (Berne, Switzerland)

IDM - Institute for Didactics of Mathematics of the University of Bielefeld (Institut für Didatik der Mathematik an der Universität Bielefeld)

IFS - Information Center for Foreign Language Research — Informationszentrum für Fremdsprachenforschung der PhilippsUniversität (Marburg)

IHF - Bavarian State Institute for Research and Planning in Higher Education (Bayerisches Staatsinstitut für Hochschulforschung und Hochschulplanung) (Munich)

IHS - Institute for Higher Education Research Wittenberg e.V. — Institut für Hochschulforschung Wittenberg e.V.

IP - Institute for Teacher Training of the Vienna University (Institut für Pädagogik an der Universität Wien) (Vienna)

IPN - Institute for Teaching the Natural Sciences of the University of Kiel (Institut für die Pädagogik der Naturwissenschaften an der Universität Kiel) (since 1997 cooperative partner)

ISP - Bavarian State Institute for School Pedagogy and Educational Research (Staatsinstitut für Schulpädagogik und Bildungsforschung) Munich)

IZI - International Central Institute for Youth and Educational Television (Internationales Zentralinstitut für das Jugend-und Bildungsfernsehen) (Munich)

KMK - Standing Conference of the State Ministries of Culture (Ständige Konferenz der Kultusminister der Länder) (KMK) (Bonn)

KRD - Catholic Religious Education Documentation Unit (Katholisches Religionspädagogische Dokumentationsstelle) (Munich) 
LSW - State Institute (of Northrhein-Westfalen) for Schools and Continuing Education (Landesinstitut für Schule und Weiterbildung) (Soest)

MPI - Max Planck Institute for Human Devolopment and Education (Max-Planck-Institut für Bildungsforschung) (West Berlin)

ODS - State School Servers and the Open School Network (nation wide)

OIJ - Austrian Institute for the Study of Youth (Österreichisches Institut für Jugendkunde) (Vienna)

PAS - Educational Center of the German Adult Education Society (PädagogischeArbeitsstelle des Deutschen Volkshochschulverbandes e.V.) (Frankfurt)

PAZ / PZ - Pedagogical Center (Pädagogisches Zentrum) (West Berlin) - after ca. 1995 this institution became the Berlin Institute for Continuing Education of Teachers and School Development (Berlin)

PHSF - Interim Project Group for Research of Higher Education (Projektgruppe Hochschulforschung) - part of former GDR Zentralinstitut für Hochschulforschung) Part of this group was integrated into the Library of the Technical University of Berlin, part has been continued by the Institute for Higher Education Research in Wittenberg

SAN e.V. - Schools on the Network (nation wide, coordinating office in Bonn)

SFZ - Cybernetic Linguistics Research Center (Sprachkybernetisches Forschungszentrum Heidelberg) (Heidelberg)

SW - School Web (Schulweb) (Directory of Schools on the World Wide Web maintained by the Dept. of Pedagogics and Informatics of the Humboldt University

UB-SSG - University Library of Erlangen - Nuremberg (DFG Special Collections Library for Education and Teaching) Universitätsbibliothek Erlangen-Nürnberg (UB-SSG)

UNIP - UNESCO Institute for Pedagogics (UNESCO Institut für Pädagogik) (Hamburg)

\section{APPENDIX C}

\section{Geographical List of Institutions}

\section{Berlin}

Berliner Institut für Lehrerfort-und-weiterbildung und Schulentwicklung (BILS / BIL) - Berlin Institute for Teacher Education and Further Education (Pädagogisches Zentrum Berlin (PZ) - Educational Center Berlin)

Bibliothek der Bildungsgeschichtlichen Forschung (BBF) - Library for Historical Educational Research (formerly the Library of the GDR APW, since 1992 integrated in DIPF)

Bundesinstitut für Berufsbildung (BIBB) - Federal Institute for Vocational Training - Documentation

Deutscher Bildungsserver (DBS) - German Educational Resources Server (maintained by the Dept. of Pedagogics and Informatics of the Humboldt University)

*Max-Planck-Institut für Bildungsforschung (MPIB) - MaxPlanck-Institute for Human Development \& Education

*Pädagogisches Zentrum Berlin (PZ) - Educational Center Berlin (as of 1995 Berliner Institut für Lehrerfort-und-weiterbildung und Schulentwicklung (BILS) - Berlin Institute for Teacher Education and Further Education
Projektgruppe Fachinformation Bildung (closely connected to the Projektgruppe Hochschulforschung) (PHSF) - Interim Project Group for Research of Higher Education (part of former GDR Zentralinstitut für Hochschulforschung) (ca. 1993-5 Bibliographic Database GDR Higher Education followed 1997 by the Institute for Higher Education Research in Wittenberg)

Schul web (SW) - School Web (Directory of Schools on the World Wide Web maintained by the Dept. of Pedagogics and Informatics of the Humboldt University

\section{Bochum}

Arbeitsstelle für vergleichende Bildungsforschung an der RuhrUniversität Bochum (AVB) - Department for Comparative Educational Research University of Bochum

\section{Bonn}

Sekretariat der Ständigen Konferenz der Kultusminister (KMK) - Secretariat of the Standing Conference of the Cultural Ministers Schulen ans Netz (SAN e.V.) - Schools on the Network 


\section{Erlangen}

Universitätsbibliothek Erlangen-Nürnberg (UB-SSG) - University Library of Erlangen - Nuremberg (DFG Special Collections Library for Education and Teaching)

\section{Frankfurt}

Deutsches Institut für Erwachsenenbildung (DIE) - German Institutefor Adult Education (formerly Pädagogische Arbeitsstelle des Deutschen Volkshochschulverbandes (PAS))

*Deutsches Institut für Internationale Pädagogische Forschung (DIPF) - German Institute for International Educational Research

Pädagogische Arbeitsstelle des Deutschen Volkshochschulverbandes e.V. (PAS) - Educational Center of the German Adult Education Society (as of 1997 Deutsches Institut für Erwachsenenbildung (DIE))

\section{Halle}

Physikdidaktischer FB der Universität Halle - Teacher Training Dept. of the University of Halle (in a cooperative agreement of Teacher Training Institutes for Physics since 1997 in FIS Bildung)

\section{Hamburg}

*UNESCO Institut für Pädagogik (UNIP) - UNESCO Institute for Education

\section{Heidelberg}

*Sprachkybernetisches Forschungszentrum Heidelberg (SFZ) Cybernetic Linguistics Research Center

\section{Karlsruhe}

Fachinformationszentrum Karlsruhe (FIZ) - Subject Information Center Karlsruhe (since 1996 in FIS Bildung)

\section{Kassel}

Physikdidaktischer FB der Universität Kassel - Teacher Training Dept. of the University of Kassel (in a cooperative agreement of Teacher Training Institutes for Physics since 1997 in FIS Bildung)

\section{Kiel}

Institut für die Pädagogik der Naturwissenschaften an der Universität Kiel(IPN) - Institute for Teaching the Natural Sciences of the University of Kiel (since 1997 cooperative partner of FIS Bildung)

\section{Koblenz}

Physikdidaktischer FB der Universität Koblenz - Teacher Training Dept. of the University of Koblenz (in a cooperative agreement of Teacher Training Institutes for Physics since 1997 in FIS Bildung)

\section{Leipzig}

Hör- und Sprechbedinderte Bibliothek (HSB) - Library for the Hearing and Speech-Impaired (part of BBF, DIPF)

\section{Marburg/Lahn}

Informationszentrum für Fremdsprachenforschung der PhilippsUniversität (IFS) - Information Center for Foreign Language Research

\section{Munich}

Bayerisches Staatsinstitut für Hochschulforschung und Hochschulplanung (IHF) - Bavarian State Institute for Research and Planning in Higher Education

Bayerisches Staatsinstitut für Schulpädagogik und Bildungsforschung (ISP) - Bavarian State Institute for School Pedagogy and Educational Research

*Deutsches Jugendinstitut (DJI) - German Youth Institute

Institut für Film und Bild in Wissenschaft und Unterricht (FWU) Institute for Film and Pictures in Science and Teaching

*Internationales Zentralinstitut für das Jugend-und Bildungsfernsehen (IZI) - International Central Institute for Youth and Educational Television

Katholisches Religionspädagogische Dokumentationsstelle (KRD) - Catholic Religious Education Documentation Unit

Physikdidaktischer FB der Universität Miinchen - Teacher Training Dept. of the University of Munich (in a cooperative agreement of Teacher Training Institutes for Physics since 1997 in FIS Bildung)

\section{Münster}

Comenius Institut - Evangelische Arbeitsstätte für Erziehungswissenschaft $(\mathrm{CI})$ - Comenius Institute - Protestant Workshop for Education

\section{Nuremberg}

Institut für Arbeitsmarkt- und Berufsforschung der Bundesanstalt für Arbeit (IAB) - Institute for Labor Market Research of the Federal Labor Office

\section{Soest}

Landesinstitut für Schule und Weiterbildung (LSW) - State Institute (of Northrhein-Westfalen) for Schools and Continuing Education

\section{Tübingen}

Deutsches Institut für Fernstudien an der Universität Tübingen (DIFF) - German Institute for Distance Education

\section{Wiesbaden}

Hessisches Institut für Bildungsplanung und Schulentwicklung (HIBS) - Hessian Institute for Educational Planning and School Development

\section{Wittenberg}

Institut für Hochschulforschung Wittenberg e.V. (IHS) - Institute for Higher Educational Research Wittenberg 
Vienna (Wien)

(Austria)

Amtsbibliothek des Bundesministeriums für Unterricht und Kunst (BMfUK) - Departmental Library of the Federal Ministry for Teaching and Art

Institut für Pädagogik an der Universität Wien (IP) - Institute for Teacher Training of the Vienna University

Österreichisches Institut für Jugendkunde (OIJ) - Austrian Institute for the Study of Youth

\section{Lower Austria (Austria)}

Bundesstaatliche Pädagogische Bibliothek beim Landesschulrat für Niederösterreich (BPD) - Federal Educational Library in the State School Board of Lower Austria

\section{Bern (Schwitzerland)}

Informationsstelle IDES (since 1997 in FIS Bildung)

\section{Zurich, Switzerland}

Pestalozzeum - Pestalozzi Center

\section{Endnotes}

Baumgardt, Hille: Der "Dokumentationsring Pädagogik" Entwicklung, Tätigkeit und Bedeutung. Hausarbeit zur Prïfung für den höheren Bibliotheksdienst. Cologne: BibliothekarLehrinstitut des Landes Nordrhein-Westfalen, 1980.

Diepold, Peter: Auf dem Weg zu einem Internet-gestiitzten, integrierten Informations-und Kommunikationssystem Bildung. In: Schnitte zur Qualiätsverbesserung von Bildungsinformationssystemen. 5. GIB-Fachtagung vom 1.-2. Oktober 1997 in Halle. Berlin: Gesellschaft Information Bildung, 1998 (in presse) http://www.educat.hu-berlin.de/ publikation/halle.html

Deutsches Institut für Internationale Pädagogische Forschung: Fachinformationssystem Bildung. Bericht iiber den Modellversuch der Bund-Länder-Kommission "Erprobung der Konzeption für ein Fachinformatiossytem Bildung." Frankfurt am Main: FIS Bildung (DIPF), 1997.

Max Planck Institute for Human Development: Center for Educational Research. Berlin: Max Planck Institute for Human Development, 1998. http://www.mpib-berlin.mpg.de/

Further information on the above institutions can be obtained from the author:

Dr. Diann Rusch-Feja

Max Planck Institute for Human Development and Education Lentzeallee 94

D-14195 Berlin, Germany

Email: ruschfeja@mpib-berlin.mpg.de

Library HomePage: http://www.mpib-berlin.mpg.de/dok/ehomee.hmm Clearinghouse for Subject-Oriented Internet Information Sources: http://www.mpib-berlin.mpg.de/dok/ech.htm

Diann Rusch-Feja is the Director of Library and Research Documentation at the Max Planck Institute for Human Development and Education, Berlin, Germany. She is also a specialist in Computer Systems for Information Systems. Previously she has taught at universities and colleges in the United States and Germany. This paper was first presented at the Annual Conference of the Special Libraries Association in Seattle, Wash., 1997. E-mail: ruschfeja@mpib-berlin.mpg.de 